\title{
ARCHEOLOGIA ZACHODNIEGO ŚRÓDZIEMNOMORZA W POZNANIU - STAN I PERSPEKTYWY BADAŃ
}

\section{WESTERN MEDITERRANEAN ARCHAEOLOGY IN POZNAŃ - STATE OF THE ART AND NEW PERSPECTIVES}

\author{
Michat Krueger ${ }^{1}$ \\ Instytut Prahistorii, Uniwersytet im. Adama Mickiewicza \\ ul. Św. Marcin 78, 61-809 Poznań, Poland
}

\begin{abstract}
Polish Mediterranean archeology has been known almost exclusively for investigations carried out in the eastern Mediterranean. The aim of the article is to present research and teaching initiatives that have been undertaken by the researchers from Poznan within the western Mediterranean for the last ninety years. For the purpose, the basic research method has been to analyze the intellectual output in form of academic thesis, monographs and articles. The library exchange, the student participation in the western Mediterraenan excavations, and the classes given in the field of Mediterranean archeology have been also analyzed.

As a result, a growing interest in the archaeology of the western part of the Mediterranean in the academic community associated with the Institute of Prehistory, Adam Mickiewicz University in Poznań has been observed, and thus detailed reasons why research in the area should be developed were listed.
\end{abstract}

Dostojny Jubileusz dziewięćdziesięciolecia istnienia akademickiej archeologii w Poznaniu skłania ku refleksji nad stanem badań zachodniego Śódziemnomorza jako integralnej części rozwijanej w stolicy Wielkopolski ze zmiennym szczęściem, ale niemal od początku, archeologii obszarów śródziemnomorskich. Nie potrzeba przeprowadzać kwerendy archiwalnej, by stwierdzić, iż obszar ten nieodmiennie stanowił peryferyjny teren badawczy. Sytuacja ta nie budzi zdziwienia przede

\footnotetext{
${ }^{1}$ Autor składa serdeczne podziękowania Organizatorom za zaproszenie na Konferencję Jubileuszową „Archeologia uniwersytecka w Poznaniu. Jej wczoraj i dziš” (Obrzycko, 2-3 lipca 2009 r.) oraz za możliwość opublikowania wygłoszonego tam referatu. Owa praca nie doszłaby do skutku, gdyby nie bardzo cenne sugestie prof. dr hab. Aleksandry Cofty-Broniewskiej, życzliwa pomoc dr Ewy Bugaj oraz Pań z Biblioteki Instytutu Prahistorii: dr Barbary Stolpiak oraz mgr mgr Małgorzaty Hojny, Lucyny Leśniak i Jolanty Walkiewicz. Autor jest również wdzięczny mgr Marcie Bartkowiak i dr. Łukaszowi Orylskiemu za krytyczne uwagi do artykułu.
} 
wszystkim dlatego, iż odrębna specjalizacja śródziemnomorska powołana została dopiero w 1997 r., natomiast pierwszy nabór na studia odbył się w 1999 r. W żadnym wypadku nie można jednak powiedzieć, że jest to dyscyplina na poznańskim uniwersytecie młoda: jej tradycja sięga czasów przedwojennych. Powodem, dla którego zachodnie Śródziemnomorze nie znalazło się w kanonie obowiązującej wiedzy, jest w naszym kraju tradycja postrzegania archeologii śródziemnomorskiej jako dyscypliny zajmującej się wyłącznie tak zwanym światem herodotowym, co w 2004 r. zostało w Poznaniu podkreślone przemianowaniem specjalizacji ,śródziemnomorskiej” na „orientalną i antyczną". Nazewnictwo utworzonych w 2008 r. w obrębie Instytutu Prahistorii UAM dwóch nowych pracowni ${ }^{2}$ świadczy jednak o przywiązaniu do terminu ,śródziemnomorski”, który dotyczy całego basenu Morza Śródziemnego, a nie tylko jego wschodniej części. Nazwa wykładanych w IP UAM przedmiotów również odzwierciedla tę tendencję: studenci pierwszego roku zobowiązani są do uczestnictwa w zajęciach o nazwie „Wprowadzenie do archeologii śródziemnomorskiej”. W związku z tym wydaje się zasadne zaprezentowanie inicjatyw naukowych i dydaktycznych w obrębie zachodniego Śródziemnomorza, zmierzających do wprowadzenia równowagi w rozwijanej na Uniwersytecie im. Adama Mickiewicza archeologii obszarów śródziemnomorskich.

Termin „zachodnie Śródziemnomorze”, rzecz jasna, związany jest z Morzem Śródziemnym. Obszar ten tradycyjnie jest ograniczany z jednej strony przez południk 16. długości geograficznej wschodniej ${ }^{3}$ (wschodnie wybrzeża Sycylii), natomiast z drugiej przez geograficzną granicę Morza Śródziemnego, czyli Cieśninę Gibraltarską, albo - i to jest propozycja, która zyskuje aprobatę większości badaczy - atlantyckie wybrzeża Portugalii i Maroka. Za poparciem takiego punktu widzenia przemawia fakt, iż od starożytności do dziś ziemie położone nawet daleko na zachód od Słupów Heraklesa były i są nieoderwalnie związane z kulturą śródziemnomorską, dobrze wpisując się, mimo widocznych odrębności kulturowych, w krajobraz znany z obszarów zamkniętych linią brzegową Morza Śródziemnego. Z tego powodu w literaturze przedmiotu używa się terminu ,zachodnie Śródziemnomorze” także w odniesieniu do akwenów i ziem znajdujących się na zachód od Cieśniny Gibraltarskiej ${ }^{4}$. O ile takie rozumienie pojęcia wydaje się słuszne w odniesieniu do atlantyckich (w obrębie regionu Andaluzji) wybrzeży Hiszpanii, południowej Portugalii i północnego Maroka, o tyle używanie terminu nie znajduje uzasadnienia w przypadku mówienia o północno-centralnych wybrzeżach Portugalii i południowo-centralnych wybrzeżach Maroka, ponieważ i kulturowo, i klimatycznie są to regio-

\footnotetext{
${ }^{2}$ Pracownia Archeologii Cywilizacji Śródziemnomorskich (kierownik: prof. UAM dr hab. Rafał Koliński) i Pracownia Archeologii Śródziemnomorskiej Epoki Brązu (kierownik: prof. dr hab. Janusz Czebreszuk).

${ }^{3}$ Okolice 16. południka stanowiły umowną granicę między wpływami cywilizacyjnymi Zachodu i Wschodu, począwszy od I tys. p.n.e.

${ }^{4}$ Díes Cusí 1994, 326.
} 
ny zupełnie różne od śródziemnomorskich. Problematyczne są również północne i południowe granice zachodniego Śródziemnomorza, ujmowane zwyczajowo jako pas wybrzeża o szerokości do około $200 \mathrm{~km}$. Warto przy tym zauważyć, że zaplecze owego pasa jest przez niektórych traktowane również jako strefa śródziemnomorska ${ }^{5}$.

Poszukiwania uniwersyteckich inicjatyw w obrębie zainteresowań zachodnim Śródziemnomorzem można zrealizować na trzech płaszczyznach: działalności stricte naukowej, działalności dydaktycznej oraz tej związanej z funkcjonowaniem biblioteki. Jest również możliwe wyróżnienie pięciu okresów w aktywności poznańskich archeologów ${ }^{6}$ : przedwojennego, powojennego do 1952 r. (czyli do powstania Katedry Archeologii Śródziemnomorskiej), 1952-1969 (do likwidacji Katedry Archeologii Śródziemnomorskiej), 1969-1999 (czyli do początku funkcjonowania specjalności śródziemnomorskiej) i najnowszego - od 1999 r. do chwili obecnej.

\section{OKRES PRZEDWOJENNY}

W najwcześniejszym, przedwojennym, okresie funkcjonowania uniwersyteckiej placówki archeologicznej jest niewiele śladów naukowej działalności w obrębie zachodniej części Morza Śródziemnego. W wydanym w Poznaniu w 1919 r. pierwszym numerze Przegladu Archeologicznego znaleźć można krótki, anonimowy artykuł o tytule „Nowe odkrycia szczątków ludzkich dyluwialnych w Hiszpanji”. W latach 20. we wspomnianym czasopiśmie pojawiły się dwie recenzje autorstwa prof. dr. hab. Józefa Kostrzewskiego, dotyczące francusko- i hiszpańskojęzycznych książek z zakresu prahistorii Półwyspu Iberyjskiego ${ }^{7}$. Dostrzec można w tych publikacjach nie tylko rozległe zainteresowania naukowe prof. J. Kostrzewskiego, ale przede wszystkim potrzebę informowania polskiego środowiska prahistoryków o inicjatywach badawczych podejmowanych również na odległych terenach zachodniośródziemnomorskich.

W latach 30. opublikowany został artykuł dr Mieczysławy Ruxer na temat etruskiej bransolety $\mathrm{z}$ Cerveteri ${ }^{8}$. Wśród poznańskich archeologów to właśnie wspomniana badaczka zajmowała się archeologią klasyczną obszarów śródziemno-

\footnotetext{
${ }^{5}$ Zdaniem wybitnego francuskiego badacza prof. F. Braudela: „Region śródziemnomorski rozciąga się (...) od pierwszego drzewa oliwnego, jakie napotkamy idąc z północy na południe, do pierwszych zwartych plantacji palmowych, pojawiających się jednocześnie z pustynią" (Braudel et al. 1982, s. 14).

${ }^{6} \mathrm{Na}$ temat periodyzacji dziejów Instytutu Prahistorii UAM zob. Cofta-Broniewska 1993. Z. Klanowski (1965, s. 195-196) wyróżnia z kolei dwa okresy w działalności naukowo-badawczej Katedry Archeologii Śródziemnomorskiej.

${ }^{7}$ Kostrzewski 1922-1924, 145-146; 1925-1927, 73.

${ }^{8}$ Ruxer 1936.
} 
morskich - i w związku z jej aktywnością naukową można szukać śladów zainteresowania zachodnią częścią Śródziemnomorza. Mieczysława Ruxer (1881-1957) wykształcenie zdobyła na Uniwersytecie Jagiellońskim w zakresie filologii i archeologii klasycznej pod kierunkiem przede wszystkim prof. dr. hab. Piotra Bieńkowskiego, który w końcowym okresie studiów był jej opiekunem naukowym². Po obronie pracy doktorskiej na macierzystej uczelni przeniosła się na Uniwersytet Poznański, gdzie od trymestru letniego roku akademickiego 1922/1923 prowadziła wykłady zlecone. Rok później została kierownikiem Seminarium Archeologii Klasycznej $^{10}$, a w następnym roku akademickim (1925/1926) objęła funkcję zastępcy profesora archeologii klasycznej ${ }^{11}$. W czerwcu 1937 r. dr M. Ruxer obroniła rozprawę habilitacyjną na Uniwersytecie Jagiellońskim, a dwa lata później do Ministerstwa Wyznań Religijnych i Oświecenia Publicznego wpłynął wniosek o nadanie jej tytułu profesora nadzwyczajnego, zrealizowany dopiero w $1949 \mathrm{r} .^{12}$

Przed wojną dr M. Ruxer prowadziła wykłady, których tematyka obejmowała przede wszystkim zagadnienia z zakresu sztuki i architektury Greków i Rzymian. Wśród spisu zajęć można jednak znaleźć również takie, których przedmiotem były zachodnie obszary Morza Śródziemnego. Na przykład w trzecim trymestrze roku akademickiego $1925 / 1926$ odbywały się zajęcia z malarstwa etruskiego ${ }^{13}$, powtórzone $\mathrm{w}$ drugim trymestrze roku akademickiego 1928/1929 $9^{14}$. Natomiast $\mathrm{w}$ roku akademickim 1925/1926, w trymestrze poprzedzającym wykłady z malarstwa etruskiego, dr M. Ruxer prowadziła zajęcia zatytułowane „Historia odkryć archeologicznych w XIX i XX wieku"15 - i chociaż brakuje szczegółowych informacji o treści wykładanego przedmiotu, to jednak nie ma powodów, by sądzić, iż nauczyciel akademicki władający, poza językiem niemieckim, także francuskim i włoskim zupełnie ignorował dzieje aktywności naukowej w zachodniej części Śródziemnomorza. $\mathrm{Z}$ podobnym problemem, związanym z brakiem danych na temat zakresu przekazywanej wiedzy, spotkać się można w przypadku przedmiotów, takich jak „Kultura rzymska prowincjonalna” (rok akademicki 1928/1929, trzeci trymestr) ${ }^{16}$ czy „Drogi handlowe świata grecko-rzymskiego” (rok akademicki 1931/1932, trzeci trymestr ${ }^{17}$. Cykl wykładów, którego tło geograficzne stanowiło bezdyskusyjnie zachodnie Śródziemnomorze, nosił tytuł „Miasta greckie we Włoszech i na Sycylii”

\footnotetext{
${ }^{9}$ Gąsiorowski 1956, s. 499; Parnicki-Pudełko 1972, 9.

${ }^{10}$ Kronika 1929, 50.

${ }^{11}$ Kronika 1926, 35.

${ }^{12}$ Archiwum Uniwersytetu im. Adama Mickiewicza w Poznaniu, teczka „Ruxerówna Mieczysława”, sygnatura 15/611/26.

${ }^{13}$ Spis wykładów 1924.

${ }^{14}$ Spis wykładów 1928.

${ }^{15}$ Spis wykładów 1925.

${ }^{16}$ Spis wykładów 1928.

${ }^{17}$ Spis wykładów 1931, 59 .
} 
i był prowadzony w trzecim trymestrze roku akademickiego $1928 / 1929^{18}$, podobnie jak „Rzym, jego dzieje i zabytki”, prowadzony w trzecim trymestrze roku akademickiego 1931/1932 $2^{19}$.

\section{OKRES POWOJENNY DO 1952 ROKU}

Przedstawione powyżej informacje świadczą, iż działalność dydaktyczna i naukowa przedwojennego okresu w obrębie zachodniego Śródziemnomorza obejmowała swoim zasięgiem jedynie Półwysep Apeniński. Tendencja ta utrzymała się również po wojnie; wykładów ze sztuki etruskiej można było słuchać jeszcze przez dwa lata, aż do 1947 roku $^{20}$, a nawet (w roku akademickim 1945/1946) istniała możliwość wyboru etruskologii jako działu specjalizacji w obrębie magisterium ${ }^{21}$. Później nastąpiła zapaść: rok akademicki 1948/1949 był ostatnim, w którym istniała możliwość uzyskania magisterium w zakresie archeologii klasycznej; z list dydaktycznych zniknęły również wszelkie przedmioty związane z zachodnim Śródziemnomorzem.

W 1949 r. prof. dr hab. M. Ruxer ogłosiła drukiem swoje badania nad etruskimi zabytkami z Muzeum Czartoryskich w Krakowie ${ }^{22}$. W tym samym roku opublikowany został przez Janusza Orłowskiego, archeologa z Krakowa, artykuł pod tytułem „Wschodnio- i południowo-hiszpańska sztuka skalna" ${ }^{23}$ w czasopiśmie Z Otchtani Wieków, organie wydawniczym najpierw Katedry Prehistorycznej Uniwersytetu Poznańskiego, a później Polskiego Towarzystwa Prehistorycznego i Muzeum Prehistorycznego w Poznaniu. Jest to odosobniony, ale ciekawy przykład popularyzacji w Poznaniu prahistorii zachodniego Śródziemnomorza.

Okres pierwszych powojennych lat charakteryzował się również nabytkami bibliotecznymi, uzyskiwanymi zwykle drogą wymiany. O ile nie ma przedwojennych źródeł co do wymiany bibliotecznej z zachodniośródziemnomorskimi ośrodkami, bądź tymi, które zajmowały się badaniem archeologii zachodniego Śródziemnomorza, o tyle od wczesnych powojennych lat można zaobserwować tendencję do uzupełniania księgozbioru o nowe pozycje. Od 1948 r. do Instytutu trafiał wydawany w Paryżu Bulletin de la Société Préhistorique Française oraz publikowana we Florencji Rivista di Scienze Preistoriche ${ }^{24}$, natomiast cztery lata później zapoczątkowa-

\footnotetext{
${ }^{18}$ Spis wykładów 1928.

${ }^{19}$ Spis wykładów 1931.

${ }^{20}$ Spis wykładów 1946, 71.

${ }^{21}$ Spis wykładów 1945, 56.

${ }^{22}$ Ruxer 1949.

${ }^{23}$ Orłowski 1949.

${ }^{24}$ Wykaz instytucji 1948.
} 
no współpracę z Katalońskim Muzeum Archeologicznym z siedzibą w Barcelonie, której owocem było czasopismo Ampurias (Empúries), wymieniane z IP UAM do chwili obecnej.

W 1952 r. Katedrę Archeologii Klasycznej przemianowano na Katedrę Archeologii Śródziemnomorskiej, natomiast prof. M. Ruxer została przeniesiona do Katedry Historii Sztuki, gdzie zajmowała się prowadzeniem wykładów ze sztuki starożytnej dla studentów historii sztuki ${ }^{25}$. Oznaczało to kres działalności naukowej zarówno Katedry Archeologii Śródziemnomorskiej, jak i samej prof. M. Ruxer - i to nie tylko w zakresie jej zainteresowań zachodnim Śródziemnomorzem.

\section{LATA 1952-1969}

Kolejny okres (1952-1969) związany jest przede wszystkim z reaktywacją w 1958 r. Katedry Archeologii Śródziemnomorskiej ${ }^{26}$. Jej działalność dydaktyczna ograniczała się do prowadzenia wykładów kursowych dla studentów archeologii, historii sztuki oraz filologii klasycznej. Dorobek naukowy tych 17 lat jest ubogi; liczy zaledwie trzy artykuły, które związane są z zachodnią częścią basenu Morza Śródziemnego. W 1952 r. młody wychowanek poznańskiej archeologii, mgr Stanisław Jasnosz, opublikował artykuł o etruskich naczyniach brązowych z terenów Wielkopolski ${ }^{27}$. W 1960 r. asystent zmarłej prof. M. Ruxer na podstawie notatek jej autorstwa dokończył opracowanie kolekcji etruskiej z Czerniejewa ${ }^{28}$. W 1959 r. zostało opublikowane bardzo potrzebne i w dużej mierze wciąż aktualne opracowanie $^{29}$ autorstwa Jana Leona Łuki na temat importów italskich $\mathrm{z}$ terenów ziem polskich, przedstawione w 1961 r. na Uniwersytecie im. Adama Mickiewicza jako praca doktorska. Spośród innych prac uniwersyteckich w Kronice UAM można znaleźć wzmiankę, iż w 1967 r. mgr B. Pawlak opracowała fragmenty fresków pompejańskich znajdujących się w zbiorach Katedry Archeologii Śródziemnomorskiej ${ }^{30}$. Znów więc zachodnie Śródziemnomorze nie jawi się jako obszar badawczy, ale funkcjonuje jako tło kulturowe badanych przez poznańskich archeologów zabytków odkrywanych na ziemiach polskich i/albo pochodzących z polskich kolekcji.

\footnotetext{
${ }^{25}$ Kronika 1958, 371-372.

${ }^{26}$ Kronika 1961, 130.

${ }^{27}$ Jasnosz 1952.

${ }^{28}$ Kubczak, Ruxer 1960.

${ }^{29}$ Łuka 1957-1959. Na marginesie warto wspomnieć, że praca ta po części znalazła swoją twórczą kontynuację w: Łuka 1963.

${ }^{30}$ Kronika UAM 1969, 226.
} 


\section{LATA 1969-1999}

30 sierpnia 1969 r. zlikwidowano Katedrę Archeologii Śródziemnomorskiej $\mathrm{UAM}^{31}$. Przerwa w rozwoju archeologii śródziemnomorskiej na Uniwersytecie im. Adama Mickiewicza trwała trzydzieści lat. W owym okresie doszło jednak dzięki wymianie bibliotecznej do znacznego poszerzenia zbioru czasopism w Bibliotece Katedry Archeologii UAM (późniejszy Instytut Prahistorii UAM), przede wszystkim włoskich. Szczególnie intensywny napływ miał miejsce w latach 70., kiedy niemal co roku katalogowany był nowy tytuł: w 1972 r. Bullettino di Paletnologia Italiana (Rzym, Włochy), w 1973 r. Rivista di Studi Liguri (Borelighera, Włochy), w 1975 r. Setúbal Arqueológica (Setúbal, Portugalia), w 1976 r. Preistoria Alpina (Trento, Włochy), w 1977 r. Rivista di Scienze Preistoriche (Florencja, Włochy), w 1979 r. Origini. Preistoria e protostoria delle civiltà antiche (Rzym, Włochy). Potem nastąpiło znaczne spowolnienie: w 1981 r. uzyskano ACME. Annali della Facoltà di Lettere e Filosofia dell'Università degli Studi di Milano (Mediolan, Włochy), a w 1994 r. przybyła w instytutowym księgozbiorze Rivista dell'Istituto Nazionale d'Archeologia e Storia dell'Arte (Rzym, Włochy).

Jest rzeczą oczywistą, iż z powodu braku archeologów śródziemnomorskich, odpowiednich struktur administracyjnych i wreszcie zainteresowań badawczych pracowników Instytutu Prahistorii UAM, skierowanych przede wszystkim na archeologię Niżu Środkowoeuropejskiego, działalność naukowa związana z zachodnim Śródziemnomorzem w tym okresie rozwijała się dość niemrawo. Tym bardziej warto wymienić nieliczne inicjatywy związane z tym obszarem. Chęć poznania zachodniej części basenu Morza Śódziemnego znalazła wyraz w zorganizowaniu w 1986 r. objazdu naukowego po Półwyspie Iberyjskim. Była to inicjatywa studencka, koordynowana przez Koło Naukowe Studentów Archeologii. Znane jest również jedno kompleksowe opracowanie ${ }^{32}$ importu etruskiego $\mathrm{z}$ terenów ziem polskich; jest to więc praca zgodna $\mathrm{z}$ kierunkiem wyznaczonym przez prof. M. Ruxer już w latach 30. Innym przykładem zainteresowania zachodnią częścią basenu Morza Śródziemnego jest recenzja pokonferencyjnego tomu na temat kultury pucharów dzwonowatych w zachodnim Śródziemnomorzu ${ }^{33}$. Ta ostatnia publikacja jest przejawem nie tylko ciekawości archeologii mało znanego w Polsce regionu, lecz przede wszystkim dowodzi, iż istnieje autentyczna potrzeba znajomości wyników badań prowadzonych na owym obszarze, szczególnie w przypadku wspólnego charakteru zjawisk kulturowych obejmujących większą część kontynentu europejskiego.

\footnotetext{
${ }^{31}$ Kronika UAM 1975, 212.

${ }^{32}$ Fogel, Makiewicz 1989.

${ }^{33}$ Makarowicz 1997.
} 


\section{OKRES NAJNOWSZY}

Najnowszy okres w dziejach zainteresowań archeologią zachodniego Śródziemnomorza związany jest $\mathrm{z}$ początkiem funkcjonowania od roku akademickiego 1999/2000 specjalności śródziemnomorskiej. Osobą, która kontynuuje poznańskie zainteresowania Półwyspem Apenińskim, jest dr Ewa Bugaj, a jej badania i działalność dydaktyczna ${ }^{34}$ skupiają się m.in. wokół problematyki etruskiej i rzymskiej ${ }^{35}$. Mgr Anna Jankowiak specjalizuje się w archeologii okresu rzymskiego, zwłaszcza obecnej Portugalii ${ }^{36}$, prowadząc badania terenowe oraz zajęcia dla studentów ${ }^{37}$. Naukowe kontakty z Hiszpanią podtrzymywane są dzięki dr Marii Ruiz del Árbol, badaczki z madryckiego Centro Superior de Investigaciones Científicas, która przebywa obecnie w Instytucie Prahistorii UAM w charakterze profesora wizytującego. Piszący te słowa zajmuje się natomiast Półwyspem Iberyjskim, również w aspekcie dydaktycznym ${ }^{38}$, a w szczególności obecnością fenickich żeglarzy i kupców w obszarze zachodniego Śródziemnomorza ${ }^{39}$.

Spośród prac magisterskich i licencjackich zdeponowanych w bibliotece Instytutu Prahistorii UAM wyróżnić można zaledwie jeden tytuł związany ze strefą zachodniośródziemnomorską: „Lokalne wpływy kulturowe w architekturze sakralnej

34 „Archeologia i sztuka starożytnego Rzymu” - obowiązkowe wykłady i ćwiczenia dla studentów III roku specjalności śródziemnomorskiej (od 2004 r. orientalnej i antycznej) prowadzone corocznie.

${ }^{35}$ Bugaj 2004; 2005; 2006a; 2006b; 2007a; 2007b; 2008; 2010a; 2010b.

${ }^{36}$ Mgr A. Jankowiak jest wykonawcą kierowanego przez dr. F. Teichnera projektu „Häuser aus Mirobriga“ i przygotowuje pracę doktorską pod kierunkiem prof. UAM dr hab. D. Minty-Tworzowskiej o tytule „Handel i wymiana jako czynniki akulturacji. Starożytna Mirobriga w kontekście rzymskich osiedli prowincji Luzytanii”.

${ }^{37}$ Poza zajęciami kursowymi, dotyczącymi archeologii, architektury i sztuki starożytnego Rzymu, mgr A. Jankowiak prowadziła w semestrze letnim roku akademickiego 2012/2013 przedmiot fakultatywny dla studentów specjalności orientalnej i antycznej: „Na krańcu świata - Iberia w czasach rzymskich".

38 „Półwysep Iberyjski w starożytności” - przedmiot faktultatywny dla studentów specjalności śródziemnomorskiej, prowadzony w semestrze zimowym roku akademickiego 2004/2005; „Okres orientalizujący w basenie Morza Śródziemnego" - zajęcia specjalizacyjne dla studentów IV roku specjalności orientalnej i antycznej, prowadzone w semestrze zimowym roku akademickiego 2008/2009 oraz w semestrze letnim roku akademickiego 2013/2014 dla studentów III roku specjalności orientalnej i antycznej; „Archeologia zachodniego Śródziemnomorza” - przedmiot fakultatywny dla studentów studiów licencjackich, prowadzony w semestrze zimowym roku akademickiego 2012/2013; ,Kolonizacja fenicka obszarów śródziemnomorskich" - przedmiot fakultatywny dla studentów studiów licencjackich, prowadzony w semestrze zimowym roku akademickiego 2013/2014; i „Półwysep Iberyjski w epoce żelaza" - przedmiot fakultatywny dla studentów studiów licencjackich, prowadzony w semestrze zimowym roku akademickiego 2013/2014.

${ }^{39}$ Krueger 2004, 2005, 2007; López Bertran, Garcia Ventura, Krueger 2008; Krueger 2009a, 2009b; Sciortino, Krueger 2009; Krueger 2010; Krueger 2011. Prace te będą kontynuowane: w chwili oddawania tego artykułu do druku autor dowiedział się o przyznaniu mu przez Narodowe Centrum Nauki grantu na dwuletnie badania archeologiczne na terenie Półwyspu Iberyjskiego. 
na terenie zachodnich prowincji rzymskiej Afryki Północnej”,40 autorstwa mgr Michaliny Dzwoniarek. Dużo lepiej natomiast przedstawia się studencka aktywność wykopaliskowa o wyraźnie rosnącej tendencji. Obszarami najczęściej ${ }^{41}$ odwiedzanymi przez studentów archeologii IP UAM w ramach praktyk wykopaliskowych były Półwysep Iberyjski ${ }^{42}$ i Półwysep Apeniński ${ }^{43}$. Stanowisko Santa Margarita położone pod Barceloną jest badane od 2007 r. również przez studentów IP UAM, którzy rokrocznie przyjeżdżają do Hiszpanii dzięki życzliwości prof. dr Rosario Navarro Saez z Uniwersytetu w Barcelonie w ramach studenckiej wymiany wykopaliskowej. Studenci tej uczelni mają natomiast możliwość uczestniczyć w pracach archeologicznych w Bierzwniku prowadzonych przez dr Barbarę Stolpiak. W 2009 r. została podpisana $\mathrm{w}$ ramach projektu Erasmus-Socrates umowa $\mathrm{z}$ Uniwersytetem w Barcelonie, na mocy której dwóch studentów IP UAM wyjechało na trzymiesięczne stypendium. Wcześniej jedynym krajem z obszaru zachodniego Śródziemnomorza objętym współpracą europejską Erasmus-Socrates były Włochy; włoska uczelnia, Università degli Studi di Siena, oferowała dwa półroczne stypendia dla naszych studentów.

W marcu 2013 r. niżej podpisany wspólnie z dr. hab. Andrzejem Michałowskim zorganizował autokarowy objazd naukowy dla II roku archeologii po kolekcjach muzealnych i najważniejszych stanowiskach archeologicznych Katalonii. W objeździe wzięło również udział kilkoro pracowników i doktorantów, a także niektórzy studenci wszystkich lat studiów licencjackich i magisterskich.

Biblioteka Instytutu Prahistorii UAM w ostatnim okresie wzbogaciła się o trzy nowe tytuły czasopism: Zephyrus. Revista de Prehistoria y Arqueología wydawany w Salamance, którego pojedyncze numery napływają od 2004 r., podobnie jak Pyrenae wydawany w Barcelonie. Trzecim tytułem jest Huelva Arqueológica; niemal kompletny zbiór tego czasopisma, wydawanego w Huelva, uzyskano w 2005 r. Również księgozbiór uległ wzbogaceniu przede wszystkim o książki wydawane w Hiszpanii - otrzymane w darze ${ }^{44}$ lub uzyskane dzięki wymianie bibliotecznej ${ }^{45}$.

\footnotetext{
${ }^{40}$ Oprócz wspomnianej wcześniej pracy dotyczącej żeglugi fenickiej istnieje co prawda praca magisterska autorstwa E. Kuciewicz (2002), jednak tytułowy płaskowyż Tessili-N-Ajjer w Algierii wykracza poza strefę śródziemnomorską, postrzeganą w Afryce jako pas wybrzeża między morzem a pustynią.

${ }^{41}$ Brakuje zorganizowanego uczestnictwa w badaniach terenowych Północnej Afryki. Na południu Francji w 2008 r. dwie osoby uczestniczyły w pracach wykopaliskowych w Tende.

${ }^{42}$ W 2003 r. w praktykach uczestniczyła jedna osoba (Castro Marim, Portugalia), w 2006 r. dwie osoby (Bilbilis, Hiszpania), w 2007 r. cztery osoby (trzy w Santa Margarida, Hiszpania, i jedna w Zambujal, Portugalia), w 2008 r. pięć osób (cztery w Santa Margarida, Hiszpania, i jedna w Zambujal, Portugalia). Powyższe dane dotyczą jedynie oficjalnych praktyk wykopaliskowych zaliczanych przez IP UAM.

${ }^{43}$ W 2003 r. oraz w latach 2005-2006 do Rzymu wyjechały na praktyki trzy osoby. W 2007 r. jedna osoba uczestniczyła w praktykach w Faragola, Włochy. Powyższe dane dotyczą jedynie oficjalnych praktyk wykopaliskowych zaliczanych przez IP UAM.

${ }^{44}$ Przede wszystkim dzięki Panu Joanowi Oriolowi z Barcelony.
} 


\section{PERSPEKTYWY ARCHEOLOGII ZACHODNIEGO ŚRÓDZIEMNOMORZA}

W tym miejscu można zamknąć ten krótki rys historyczny dotyczący zainteresowań zachodnim Śródziemnomorzem w Poznaniu. Dorobek, jak na 90 lat istnienia uniwersyteckiej archeologii, jest niewielki. Podstawową przeszkodą, która uniemożliwiała prowadzenie działalności naukowej w zachodniej części basenu Morza Śródziemnego, była oczywiście sytuacja polityczna Europy Wschodniej po drugiej wojnie światowej. Warto jednak zaznaczyć, że brak badań w zachodnim Śródziemnomorzu nie jest wyłącznie polską specyfiką. Stosunkowo niedawno, bo w 1997 r., w prestiżowym brytyjskim wydawnictwie Routledge ukazała się książka The Archaeology of Iberia ${ }^{46}$. Na jej okładce znaleźć można symptomatyczny dla omawianego problemu zapis, będący jednocześnie zachętą do zainteresowania się najstarszą przeszłością Półwyspu Iberyjskiego: „For many archaeologists, Iberia is the great unknown region in Europe. Although it occupies a crucial position between south-western Europe and North Africa, academic attention has traditionally been focused on areas such as Greece or Italy. However, Iberia has an equally rich cultural heritage and archaeological traditions (...)”. Półwysep Iberyjski nie jest tu wyjątkiem, również północna Afryka czy też zachodniośródziemnomorskie wyspy nie doczekały się należytego zainteresowania nie tylko w obrębie polskiej archeologii, lecz także tej europejskiej. Trzeba bowiem zauważyć, że cytowany tekst został napisany z perspektywy archeologii brytyjskiej, znanej z prowadzonych badań w wielu regionach świata.

Dlaczego więc warto zajmować się archeologią zachodniego Śródziemnomorza? Odpowiedź na to pytanie została już częściowo udzielona. Po pierwsze, w skali międzynarodowej obszar zachodniego Śródziemnomorza, mający bardzo wysokie walory kulturowe, jest wciąż słabo rozpoznanym terenem ${ }^{47}$. Brak tradycji badań w tej części Śródziemnomorza, przy jednoczesnym deklarowaniu uprawiania archeologii śródziemnomorskiej, stanowi podstawę do zmiany tego stanu rzeczy.

Po drugie, archeologia zachodniego Śódziemnomorza, w szczególności terenów europejskich, jest ważna dla poszerzenia perspektywy archeologii Niżu Środkowoeuropejskiego i zrozumienia fenomenów tam występujących, które mogą mieć swoje paralele właśnie na Zachodzie ${ }^{48}$. W tym miejscu warto zacytować stwierdze-

\footnotetext{
${ }^{45}$ Najwięcej książek uzyskano z Uniwersytetu Pompeu Fabra w Barcelonie.

${ }^{46}$ Díaz-Andreu, Keay 1997.

${ }^{47}$ Rzecz jasna, archeologia poszczególnych państw omawianego obszaru jest obfita w studia nad wszystkimi epokami pradziejów. Problem stanowi jednak dyfuzja owych opracowań i umiędzynarodowienie wyników lokalnych badań.

${ }^{48}$ Podczas przygotowywania pracy doktorskiej (Krueger 2011) autor tego artykułu znalazł wiele inspiracji do wyjaśnienia fenomenów obserwowalnych w kulturze materialnej interesującego go stanowiska właśnie w archeologii Niżu Środkowoeuropejskiego. Szukanie owych inspiracji z powodzeniem może odbywać się również „,w drugą stronę”.
} 
nie prof. dr. hab. Jana Żaka, który w pełni rozumiał znaczenie badania obszarów śródziemnomorskich w kontekście archeologii Polski: „Nie można ujmować paleolitu «polskiego»w oderwaniu od paleolitu afro-euro-azjatyckiego, nie można mieć wizji neolitu europejskiego i przednioazjatyckiego, byłoby nonsensem naukowym rozpatrywanie problematyki «polskiej» epoki metali łącznie ze średniowieczem, bez odniesienia do tychże w strefie europejskiej i wybrzeży śródziemnomorskich (...) z ich zapleczem, 49 .

Po trzecie, archeologia zachodniej części basenu Morza Śródziemnego może stać się atrakcyjną wizytówką promującą Instytut Prahistorii. Jeżeli o potencjale uniwersyteckiej jednostki, idąc za autorami „Strategii promocji Wydziału Historycznego UAM" ${ }^{\text {,50 }}$, świadczą m.in. takie cechy, jak ,(...) kontakty z uczelniami w kraju i za granicą (staże, programy wymiany studentów), organizacja badań terenowych w kraju i za granicą, różnorodna oferta edukacyjna, specjalistyczne studia na kierunkach niedostępnych na innych uczelniach (...), ${ }^{, 51}$, to rozwijanie archeologii zachodniego Śródziemnomorza powinno przyczynić się do umocnienia wizerunku IP UAM jako jednostki o nowatorskim programie badań i nauczania, a w efekcie do wzrostu zainteresowania studiami na kierunku archeologii, co ma istotne znaczenie w obliczu postępującego niżu demograficznego.

Na podstawie przytoczonych faktów można stwierdzić, że brak badań zachodniego Śródziemnomorza w Poznaniu spowodowany był zbyt szczupłymi możliwościami kadrowymi w Instytucie Prehistorycznym, gdzie archeologię klasyczną reprezentowała tylko prof. M. Ruxer. Po drugiej wojnie światowej to przede wszystkim izolacja polityczna zadecydowała o wykluczeniu obszarów zachodniośródziemnomorskich z obowiązującego kanonu wiedzy o archeologii basenu Morza Śródziemnego. Obecna sytuacja nauki i szkolnictwa wyższego w Polsce, będącego $\mathrm{w}$ procesie integracji z europejskimi standardami, bardziej niż kiedykolwiek umożliwia realizację międzynarodowych przedsięwzięć, których celem mogą stać się obszary zachodniego Śródziemnomorza. Powstała więc możliwość, by w chwili definiowania poznańskiej archeolgii śródziemnomorskiej uzupełnić ją o budowaną od podstaw specjalizację, do tej pory nieistniejącą nie tylko na polskich uniwersytetach, lecz także, poza nielicznymi wyjątkami, w Europie.

\section{BIBLIOGRAFIA}

Bogacki M., Piesiak-Robak A., Tatarkiewicz A.

2009 Strategia Promocji Wydziału Historycznego Uniwersytetu im. Adama Mickiewicza w Poznaniu, Poznań.

\footnotetext{
${ }^{49}$ Żak 1987, 242.

${ }^{50}$ Bogacki, Piesiak-Robak, Tatarkiewicz 2009.

${ }^{51}$ Bogacki, Piesiak-Robak, Tatarkiewicz 2009, 15.
} 
Braudel F., Coarelli F., Aymard M.

1982 Morze Śródziemne. Region i jego dzieje, Gdańsk.

Bugaj E.

2004 Kilka uwag na temat dziecka w kulturze starożytnego Rzymu [w:] Dusza maluczka a strata ogromna. Funeralia Lednickie 6, red. W. Dzieduszycki, J. Wrzesiński, Poznań, s. 23-28.

2005 Etruskie zwyczaje pogrzebowe oraz dary grobowe - krótki zarys problematyki [w:] Do, ut des - dar, pochówek, tradycja. Funeralia Lednickie 7, red. W. Dzieduszycki, J. Wrzesiński, Poznań, s. 137-147.

2006a O doświadczaniu starości w kulturze starożytnego Rzymu [w:] Starość - wiek spetnienia. Funeralia Lednickie 8, red. W. Dzieduszycki, J. Wrzesiński, Poznań, s. 187-195.

2006b Kopie i naśladownictwa w kulturze starożytnego Rzymu [w:] Estetyka w archeologii. Kopie i naśladownictwa, red. M. Kwapiński, Gdańsk, s. 113-124.

2007a Rzymskie cmentarzyska i pomniki nagrobne jako sztuka upamiętniania [w:] Środowisko pośmiertne człowieka. Funeralia Lednickie 9, red. W. Dzieduszycki, J. Wrzesiński, Poznań, s. 327-343.

2007b Etruscan Systems of a Goods Exchange and Communication Routes Including Regions Located North of the Alps. Outline of the Issue [w:] Long Distance Trade in the Bronze Age and Early Iron Age, Acta Universitatis Wratislaviensis No 2960, Studia Archeologiczne XL, red. J. Baron, I. Lasak, Wrocław, s. 292-314.

2008 Zaraza w świecie rzymskim w czasach Antoninów (Plague in the Roman World under the Antonine Dynasty) [w:] Epidemie, klęski, wojny. Funeralia Lednickie 10, red. W. Dzieduszycki, J. Wrzesiński, Poznań, s. 80-114.

2010a Materialne relikty starożytnej Etrurii jako owoc ówczesnych relacji społecznych. Przykład cmentarzysk (Material Culture of Ancient Etruria as a Result of Social Relations. Case Study of the Cemeteries) [w:] Tak więc po owocach poznacie ich. Funeralia Lednickie 12, red. W. Dzieduszycki, J. Wrzesiński, Poznań, s. 261-271.

2010b Starożytni Rzymianie i ich uczty (Ancient Romans and Their Banquets) [w:] Szkice humanistyczne, red. R. Koliński, A. Kotłowska, I. Barczyńska, K. Polakowski, Poznań, s. $147-163$.

Cofta-Broniewska A.

1993 Siedemdziesiąt lat Instytutu Prahistorii Uniwersytetu im. Adama Mickiewicza w Poznaniu (na marginesie wystawy jubileuszowej), Folia Praehistorica Posnaniensia 5, s. 179-185.

Díaz-Andreu M., Keay S. (red.)

1997 The Archaeology of Iberia. The Dynamics of Change, London-New York.

Díes Cusi E.

1994 Aspectos técnicos de las rutas comerciales fenicias en el Mediterráneo Occidental (s. IX-VII a. C.), Archivo de Prehistoria Levantina 21, s. 311-336.

Dzwoniarek M.

2013 Lokalne wptywy kulturowe $w$ architekturze sakralnej na terenie zachodnich prowincji rzymskiej Afryki Pótnocnej, Poznań [maszynopis pracy magisterskiej, Biblioteka Instytutu Prahistorii UAM].

Fogel J., Makiewicz T.

1989 Nieznany ,import” etruski z Kujaw, Archeologia Polski 34 (1), s. 127-159.

Gąsiorowski S.J.

1956 Mieczysława Sabina Ruxer (10 X 1891 - 5 IV 1957) i jej działalność naukowa, Archeologia 8 (2), s. 499-507. 
Jasnosz S.

1952 Etruskie naczynia brązowe z północnej Wielkopolski, Przegląd Archeologiczny 9, s. $335-340$.

Klanowski T.

1965 Uniwersytet im. Adama Mickiewicza w Poznaniu 1945-1965, Poznań.

Kostrzewski J.

1922-1924 Recenzja: „La civilisation énéolithique dans la péninsule Ibérique”, Nils Aberg, Uppsala-Lipsk-Paryż 1922, Przegląd Archeologiczny 2 (1), s. 145-146.

1925-1927 Recenzja: „La civilización megalítica catalana y la cultura pirenaica”, Luis Pericot y Garcia, Barcelona 1925, Przeglad Archeologiczny 3 (1), s. 3.

Kronika Uniwersytetu Poznańskiego za rok szkolny 1924/1925 za rektoratu prof. dr. Stanistawa Dobrzyckiego, [wyd.] 1929, Poznań.

Kronika Uniwersytetu Poznańskiego za rok szkolny 1925/1926 w czasie rektoratu prof. dra Ludwika Sitowskiego, [wyd.] 1926, Poznań.

Kronika Uniwersytetu Poznańskiego za lata akademickie 1945-1954/55, [wyd.] 1958, Poznań.

Kronika Uniwersytetu im. Adama Mickiewicza w Poznaniu za rok akademicki 1958/1959 za rektoratu Prof. Dra Alfonsa Klafkowskiego i otwarcie roku akademickiego 1959/1960 w dniu 1 października 1959 r., [wyd.] 1961, Poznań.

Kronika Uniwersytetu im. Adama Mickiewicza w Poznaniu: za lata akademickie 1965/1966-1967/1968, [wyd.] 1969, Poznań.

Kronika Uniwersytetu im. Adama Mickiewicza w Poznaniu: za lata akademickie 1969/1970-1971/1972, [wyd.] 1975, Poznań.

Krueger M.

2004 Żegluga fenicka w zachodnim Śródziemnomorzu i na Oceanie Atlantyckim, Poznań [maszynopis pracy magisterskiej, Biblioteka Instytutu Prahistorii UAM].

2005 Petroglify z Abrigo de Laja Alta (Hiszpania) w świetle analizy ikonograficznej reliefów asyryjskich [w:] Nie tylko Europa. Wybór materiałów z I Ogólnopolskiej Konferencji Orientalistów w Ciążeniu nad Warta, red. A. Joniak-Lüthi, Poznań, s. 209-217.

2007 Fenicjanie i Grecy w zachodniej części Morza Śródziemnego - współpraca czy rywalizacja? [w:] Grecy, Rzymianie i ich sasiedzi (=Antiquitas XXIX), Wroctaw, 21 IX 2005 r., red. K. Nawotka, M. Pawlak, Wrocław, s. 25-34.

2009a Some remarks on value in western Andalusia during the Orientalizing period [w:] SOMA 2008, Proceedings of the XIth Symposium on Mediterranean Archaeology, British Archaeological Reports 1909, red. H. Oniz, Oxford, s. 143-149.

2009b Algunas reflexiones metodológicas acerca de la arqueología de Tartessos, Espacio, Tiempo y Forma (serie II) 22, s. 201-209.

2010 Rezension zu: Raimon Graells i Fabregat (Coord.), El valor social i comercial de la vaixella metàl•lica al Mediterrani centre-occidental durant la protohitòria, Frankfurter elektronische Rundschau zur Altertumskunde 11, s. 34-35.

2011 Estructura social tartésica a través del ejemplo de la necrópolis de Setefilla (Lora del Río, Sevilla), Barcelona-Poznań [maszynopis pracy doktorskiej, Biblioteka Universitat Pompeu Fabra i Biblioteka Instytutu Prahistorii UAM].

Kubczak J., Ruxer M.S.

1960 Naczynia etruskie z dawnych zbiorów w Czerniejewie, Archeologia 10, s. 181-191 [opracowanie na postawie notatek zmarłej Autorki].

Kuciewicz E.

2002 Sztuka naskalna Sefaru na płaskowyżu Tessili-N-Ajjer w Algierii, Poznań [maszynopis pracy magisterskiej, Biblioteka Instytutu Prahistorii UAM]. 
López Bertran M., Garcia Ventura A., Krueger M.

2008 Could you take a picture of my boat, please? The use and significance of Mediterranean ship representations, Oxford Journal of Archaeology 27 (4), s. 341-357.

Łuka J.L.

1957-1959 Importy italskie i wschodnioalpejskie oraz ich naśladownictwa na obszarze kultury łużyckiej okresu halsztackiego w Polsce, Slavia Antiqua 6, s. 1-99.

1963 Uwagi o niektórych kontaktach Pomorza Wschodniego z basenem Morza Śródziemnego we wczesnej epoce żelaza, Archeologia Polski 8, s. 274-288.

Makarowicz P.

1997 Recenzja monografii W.H. Waldren, R.C. Kennard (red.), „Bell Beakers of the Western Mediterranean”, BAR Int. Series 331, Oxford 1987, Folia Praehistorica Posnaniensia 8, s. 206-210.

Orłowski J.

1949 Wschodnio- i południowo-hiszpańska sztuka skalna, Z Otchłani Wieków 11-12, s. 169-178.

Parnicki-Pudełko S.

1972 Słowo wstępne [w:] Naszyjnik grecki $w$ okresach hellenistycznym $i$ rzymskim, red. M.S. Ruxer, J. Kubczak, Warszawa-Poznań, s. 9-10.

Ruxer M.S.

1936 Un braccialetto ceretano dalla ex Collezione Tyszkiewicz [w:] Munera Philologica Ludovico Ćwikliński bis sena lustra professoria claudenti ab amicis collegis discipulis oblata, red. L. Ćwikliński, Poznań, s. 478-483.

Ruxer M.

1949 Etruskie terakotowe ossuaria i sarkofagi w zbiorach Muzeum im. XX. Czartoryskich w Krakowie, Sprawozdania Poznańskiego Towarzystwa Przyjaciół Nauk, I-II kwart., s. $101-103$.

Sciortino G., Krueger M.

2009 Phoenicians and Greeks in the Western Mediterranean: Interpretations and Reinterpretations, [w:] SOMA 2007, Proceedings of the XIth Symposium on Mediterranean Archaeology, British Archaeological Reports 1900, red. C. Ögzan, Oxford, s. 342-347.

Spis wykładów na 1, 2, 3 trymestr roku akademickiego 1924/25 [wyd.] 1924, Poznań: Uniwersytet Poznański.

Spis wykładów na 1, 2, 3 trymestr roku akademickiego 1925/26 [wyd.] 1925, Poznań: Uniwersytet Poznański.

Spis wyktadów na 1, 2, 3 trymestr roku akademickiego 1926/27 [wyd.] 1926, Poznań: Uniwersytet Poznański.

Spis wykładów na 1, 2, 3 trymestr roku akademickiego 1928/29 [wyd.] 1928, Poznań: Uniwersytet Poznański.

Spis wykładów na 1, 2, 3 trymestr roku akademickiego 1929/30 [wyd.] 1929, Poznań: Uniwersytet Poznański.

Spis wykładów na 1, 2, 3 trymestr roku akademickiego 1931/32 [wyd.] 1931, Poznań: Uniwersytet Poznański.

Spis wykładów na rok akademicki 1945/46 [wyd.] 1945, Poznań: Uniwersytet Poznański.

Spis wykładów na rok akademicki 1946/47 [wyd.] 1946, Poznań: Uniwersytet Poznański.

Wykaz instytucji

1948 Wykaz instytucji, z którymi Instytut Prehistoryczny Uniwersytetu Poznańskiego utrzymuje wymianę wydawnictw, Przegląd Archeologiczny 8 (1), s. 139-140.

Żak J.

1987 Poznańska prahistoria w ostatnim dziesięcioleciu, Kronika Wielkopolska 2/3 (45), s. 242. 


\title{
WESTERN MEDITERRANEAN ARCHAEOLOGY IN POZNAŃ - STATE OF THE ART AND NEW PERSPECTIVES
}

\begin{abstract}
S u m mary
The history of the Western Mediterranean archaeology in Poznań, perceived as an academic discipline, could be divided, due to the political, administrative and personnel background, into five periods: before II WW, 1945-1952, 1952-1969, 1969-1999 and 1999-present. The most important scholar who initiated in the early 1920s and then developed scientific interests in the archaeology of the Italian Peninsula was Professor Mieczysława Sabina Ruxer (1891-1957). At that time, Greek and Roman art and architecture were the main subjects of academic interests, including the expansion of classical culture to western part of the Mediterranean Sea. Also, the Etruscan art was deeply studied. After the II WW a development in the field of library exchange was observed; at least 14 archaeological journals from the Western Mediterranean region were catalogued in the library of the Department of Prehistory at the Adam Mickiewicz University in Poznań. However, in terms of investigation and education, no attention has been paid to the Iberian Peninsula, southern coast of France and north-western coast of Africa. The situation slightly changed after the foundation of the "Mediterranean archaeology" specialization in 1999. Taking into account the internationalization process of education and research within the European Union, there is a chance to broaden the perspective of Mediterranean archaeology, traditionally focused solely on Mesopotamia, Egypt, Greece and Rome.
\end{abstract}

